\title{
TEACHERS AND STUDENTS' PERCEPTION TOWARD CHARACTER EDUCATION IN ENGLISH TEXTBOOKS
}

\author{
DIO RESTA PERMANA \\ Institut Agama Islam Negeri Bengkulu, Indonesia \\ diorestapermana@iainbengkulu.ac.id \\ RITA INDERAWATI \\ Universitas Sriwijaya, Indonesia \\ ritainderawati@unsri.ac.id \\ MACHDALENA VIANTY \\ Universitas Sriwijaya, Indonesia \\ machdalenavianty@unsri.ac.id \\ DOI : http://dx.doi.org/10.29300/ling.v6i2.3823
}

\begin{abstract}
This study aimed at investigating how far teachers and students really understand the existence of character education in the curriculum, especially through the teaching and learning process in the classroom by using English textbooks as a medium. There were six teachers and six students who participated in this research. A semi-structured interview with a one-on-one interview was conducted in order to see the perspective of teachers and students about character education in their textbooks. The study revealed that both teachers' and students' agreed that character education is essential in creating good individuals with noble characters to tackle moral degradation. Their understanding of character education in the textbooks they were using now was satisfactory. It can be seen through both teachers and students were aware of dealing with character values in the textbooks that embedded in the teaching and learning materials which can be presented both in form of implicit and explicit but they did not know about 18 character values proposed by the government yet.
\end{abstract}

Keywords: Teachers' and students' perception, character education, English textbooks

\section{INTRODUCTION}

The essence of education is an attempt to shape individual because an individual is born illiterate and innumerate, and ignorant of the norms and cultural achievement. Gandhi (as cited in Behera, 2016), "Education which does not mold character is absolutely worthless." Thus, it means the provision of education actually has two objectives, to create human being with knowledge and to shape their characters. In the past, philosophers like Aristotle and Confucius define character as long process to create behavioral expectations of their students (Agboola \& Tsai, 2012). Character-based education is the responsibility of all parties such the informal education institutions that take place in the family, non-formal 

education in the community, and particularly formal education institution like school (Pala, 2011). But the most influential social institution that provides educational opportunities for individuals are the schools because children spend most of their time in schools (Battisich, 2005; Cubukcu, 2012; Lickona, 2012a; Furkan; 2013).

It is the hidden curriculum that focuses on shaping students with the desire of social norms, cultural values, and attitudes that can be implemented in the society (Cubukcu, 2012; Otewa, 2016; Afriani, 2019). It cannot be neglected that hidden curriculum as important as actual curriculum in determining educational goals (Yuksel, 2005; Mei, 2015). The hidden curriculum also refers to the aspect of the actual curricula such as content, textbook, and methods but this concept includes all implicit materials and concepts in principles and structure of the educational system, e.g. group activities in the classroom; and communication and interaction pattern in school (Azimpour \& Khalilzade, 2015; Afriani, 2019). In the relation the issues above, the writer wanted to know teachers' perception in teaching various character values to their students and students' opinion with regard to character education that embedded in our curriculum.

\section{Character Education in the 2013 Curriculum}

The word 'character' was derived from Greek language Kharassein which means to engrave a distinctive mark on an object. It can be interpreted as engraving someone mental or psychological domain to become certain values that make an individual different to each other. Agboola and Tsai (2012) argue that character education should not be taken lightly, because of the key facts that it would have foundational and everlasting effects on the children or the students. Character education can deliberate the effort to develop a good character based on core virtues that are good for the individual and good for society (Lickona, 2012a) and shoulbe based on humanity (Inderawati, 2013).

\section{Components of Good Character}

Characters are developed through three stages which are knowing, acting, and habit (Lickona, 2012a). A character is not limited to knowledge alone. A person who has good knowledge is not necessarily able to act in accordance with his knowledge if he or she is not trained (become habitual) to do good. Characters also extend to areas of emotion and habit. Thus, required three components of good character, there are moral knowing, moral feeling, and moral action. This is necessary for students to get involved in the education system to understand, feel, live, and practice moral values. 


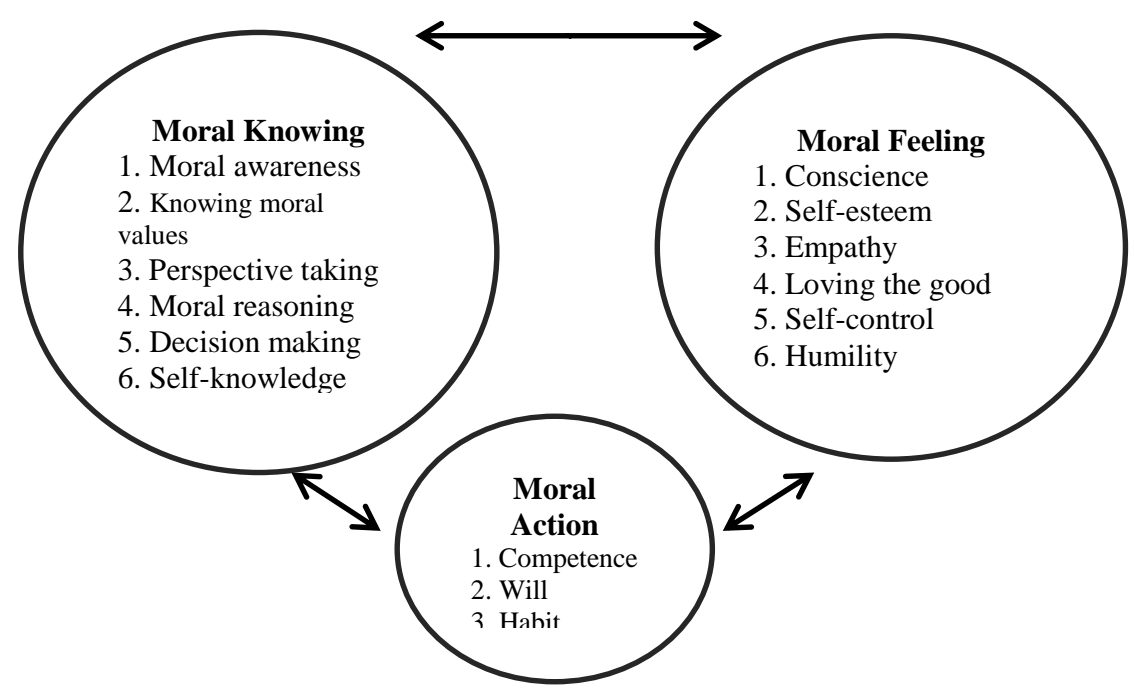

Notes: Quoted from Lickona, Mendidik untuk membentuk karakter, (2012a, p. 84).

These three components and their aspects cannot be separated since they are related to each other. The following components should be supported each other so it can create an ideal individual with good character (Lickona, 2012a). Moral knowledge, moral feeling, and moral action in its manifestation are character quality that creates moral values become a living reality. In its development, Ministry of Education (2010) concludes that in the development of student character can be divided into four stages namely (1) Anomy, students do not understand the meaning of values yet; (2) Heteronomy, students' understanding of the values emerge and it is strengthened by their closest environment but still inconsistent in the application; (3) Socionomy, students' understanding and awareness already formed and start to be consistent; and (4) Autonomy, students showing decent attitudes continuously and consistently.

\section{Character Values in the 2013 Curriculum}

The Ministry of Education and Culture has established the basis of character education that is based on Indonesian cultural education and national character. The development of character education should be sustainable, started from grade 1 to grade 12; integrated into all subjects, promoted in self-development (school routine activities, spontaneous activities, modelling and conditioning), and school culture; taught actively and enjoyable; and the values are not taught but developed which means the learning material is used as media to develop character education (Ministry of Education, 2010). In line, Berkowitz and Bier (2005) propose that character education can be introduced in professional development program, peer interaction, direct teaching, skill training, explicit agenda, 
family/community involvement, modelling/mentoring, integration into academic curriculum, and multi-strategy approach.

There are eighteen-character values that stated in the curriculum (Ministry of Education and Culture, 2010). Those 18 characters are expected to be taught in the school and expected to be acquired successfully by the students. Eventhough, not all those 18 character values will find in a textbook (Permana, 2018). Furkan (2013) explains students successful in acquiring characters can be defined through indicators achievement in students' competency standard. Generally, those indicators achievement of character education can be divided into five categories, namely: (1) character education that Related to the One and Only God, Spiritual; (2) Related to Self, such as honesty, responsibility, tolerance, discipline, perseverance, confidence, think logically, think critically, innovative, independent, curiosity, love knowledge (reading interest and knowledgeable); (3) Related to Other, such as aware between right and duty toward self and others, obedient toward social rules, appreciate others (others' work and others' achievement), well-mannered, and democracy; (4) Related to the Eenvironment like aware of environment and social situation; and (5) Related to Nation like nationalism and diversity.

\section{METHOD}

The interview was conducted to get an in-depth explanation about teachers' opinion to the six English teachers and six students in two schools in Rejang Lebong toward the official English textbooks from Indonesian government. This interview was formed as semistructured interviews (Fraenkel et al., 2012). The researcher also used one-on-one interview (Creswell, 2012). The researcher asked questions and recorded the answers from only one interviewee in the study at the time. Teachers and students' perception based on the interview were transcribed and categorized. In transcribing process, the transcription of interview was given to the participants in order to confirm and to recheck their answers and to keep the trustworthiness of the study so it could tackle ambiguity and uncertainty of the interview result. Then, the interview result was categorized into groups based on the guidelines from Fraenkel et al. (2012, p. 480). It meant the researcher extracted what he considered to be relevant statements from the teachers' and students' interview of the topic and then grouped the statements into themes. Then, the themes were explained in term of narrative description. By formulating and grouping the themes (i.e. major ideas), it was helpful for the researcher in organizing and interpreting the large amounts of descriptive information. 


\section{FINDINGS AND DISCUSSION}

\section{Findings}

In this part, it contains of teachers' and students' perception toward the existence of character education that divided into three main themes that can be described from the interviews result.

\subsection{The Important of Studying Character Values for Students}

Each teacher agree that introducing character values to the students is important and impactful for students' life so they become good individuals. Their arguments can be seen below:

"Because we want to develop the characters we expect."

(Teacher 1)

"Because from the beginning we introduce, the students who knew it, they will more active, (characters) be a part of their personalities."

(Teacher 2)

“...they will lead this country. If their character is not good, automatically as the future leaders they will fail... there is corruption and robberies happened, it is because since in the elementary, junior high school, until to the University, character education was not attached to them. If the character education has been attached to them from childhood, Insya Allah what we fear is not possible."

(Teacher 3)

"If we cultivate such characters, hopefully that the next generation could be better than today."

(Teacher 4)

"Character education is very important because when we see from the development of learners, their attitude is poor. Character education should be taught as soon as possible even in English subject."

(Teacher 5)

"Because character education is benefitial. For example, in teaching students honesty, discipline, social awareness, and responsibility. So in my opinion, character education should be taught because it is important."

(Teacher 6)

The teachers' statement confirmed that moral degradation was happening. The key success to stop this condition is through character education. Yet, from their arguments above, it can be concluded that character education should be taught as soon as possible not except English subject in order to create students to be better people for tomorrow. 


\title{
1.2.Character values distribution in the textbooks
}

Each teacher confirmed that they did not know about 18 character values proposed by the government. They believed that the presense of character values did exist in the textbooks but they cannot confirm each character. Here is some extraction from the interviews:

"The textbook does not involve whole 18 character values proposed by the government, but only partly. The rest is developed by teacher, we add by ourselves. Some government proposed character values are such as like cooperation, independence, and responsibility. Meanwhile, there are no values like discipline and confidence, so we add."

(Teacher 1)

"I do not really know about that 18 character values. But, I see that there are values like cooperation, discipline, honesty, respect to friends, social values, and cleanliness."

(Teacher 2)

\begin{abstract}
"Not yet. As I said before, there are nationalism, cooperation, spiritual, curiousity and communication existed through observing activity... I'm not too focussed on that. I think like cleanliness is there because in the book there is a material about maintaining cleanliness, we must maintain cleanliness. Like the Imperative Sentence material, there is a "Clean the whiteboard!"
\end{abstract}

(Teacher 4)

"The value is there but not that whole of 18 character values exist. So maybe $2 / 3$ of the 18 already in the textbook. For example, in the every beginning of chapters, there are values such as cooperation, learn to accept the opinions of others, then we receive-give advice to others..."

(Teacher 5)

All teachers believed that the textbooks did not contain 18 character values that proposed by the government but they claimed that there were some character values exist in the textbooks. Some teachers claimed that characters like cooperation and cleanliness were available in the textbooks, meanwhile, some of them also claimed different values. From the arguments above, it can be concluded that all teachers completely did not know about 18 character values proposed by the government yet, so it cannot cover additional values outside the proposed values for second research question of this study.

\subsection{Teachers' perspectives related to their in-used textbooks}

Based on the interviews to the six teachers, they used textbooks published by the government. This section focuses on the teachers' opinion about the content of character values in teachers' media for teaching English in the classroom.

In teachers' perspective, they claimed that they were aware about the existence of character values in the textbooks. They believed that there were some characters and it 
integrated in various learning materials in the textbooks, it can be presented in written form and also can be found in pictures. The majority of teachers claimed that the existence of characters in the textbooks were moderate and good. In addition, teachers claimed that the character education materials were majorly presented implicitly rather than explicitly. Even though the materials are majorly presented implicitly, but some of teachers explained that they still need to stress character values explicitly to the students. Here is some extractions about the existence of character education:

"For the example in giving attention, how do we call attention to students in class with appropriate words. For example "Attention please!" And then the students are also asked to say politely to the teacher, like "Sir, may I wash my hand?" So they take permission first. It is one of the characters. After the teacher permits them, they can go out. If the teacher does not allow it, they will not automatically go out. It is kind of characters, it is courtesy in English subject."

(Teacher 3)

"For example in greeting materials, such as on greeting card. It is true that the children are given that every student can give appreciation to his other friends. From there it appears that character education already exists, already embedded in teaching materials, in the material class $8 . "$

(Teacher 5)

In order to promote character education successfully, it really depends on how the way teachers teach it. Commonly, teachers can used strategy to teach values like stressing the values explicitly or delivering it indirectly to students. As far as the teachers used the textbooks, they claimed that the textbooks did not contain inappropriate materials, they did not find any obstacles in teaching character values from the textbook and they also claimed that students were comfortable dealing with character values in the textbooks. The teachers mentioned that they did not need additional materials to promote character education in the textbooks since they claimed that character values in the textbooks were enough even though they did not know about 18 character values yet. They just need to integrate it into their teaching activity. They claimed that they only used additional materials in order to fulfill their syllabus wants where it meant they only focused on linguistic competence of the learning and they usually used additional materials from the internet.

\subsection{Students' Perception about Character Values in Their In-Use Textbooks}

Based on the interviews, the six students have given their definition of character. They believed that character is an attitude of an individual. Here are some extractions from the interviews: 
"Character is something that is in the person and it is formed consciously or unconsciously, it not only seen by what he/she sees from himself/herself but also what he/she sees from the surrounding environment. "

(Student 3)

"Character is our behavior, attitude or personality."

(Student 4)

"Character is something that is attached to a person that distinguish him/her by looking at his/her trait, moral, and behavior. "

(Student 5)

Based on students' opinion above, it can be concluded that character is very related to an attitude, traits, moral values, personality, and behavior. They claimed that someone character is different each other so it is possible to distinguish someone who has good or bad character. A character can be formed through his or her environment and it needs time to do it.

\subsection{Character education is the only way to change people from bad to good}

All students agreed that character education is important to be taught. They concluded that character education is the key success to transform themselves from having bad character to good one. Their arguments can be seen below:

"Character education is important because it is able to change our attitude from bad to good... character education can appear in every subjects."

(Student 2)

"It is important. Because through character education, someone who has knowledge, he can use his knowledge in the right way... Character education must be introduced in English subjects and it is not only in English subject but also in all subjects. Because more intense the students with character education, the more accustomed they implement good characters."

(Student 3)

"It is important. Because it can change people to better than before... Character education can be started anywhere and anytime, it can be at home or at school."

(Student 4)

"It is important. Because it can turn students from bad to good and from wrong to right."

(Student 6)

The majority of the students believed that character education is very essential in strengthening their characters. They believed that through character education they will 
be able to choose what is good and right for themselves. For example, throwing garbage into a garbage bin is the example of student that have good character. Moreover, they claimed that character education should be taught anywhere, it is not only responsibility of certain subjects but also it should be taught in every subject without exception English subject. The more intense they surrounded by character education the quicker they become students with noble character.

\subsection{Characters that Junior High School students should have}

When asked about what characters that reflect good character of students, each student were able to give their opinion. They claimed that Junior High School students should have characters such as Religious, Honesty, Discipline, Respect and Cooperation. Here are some opinions from the interview:

“...Religious, nationalism, independence, cooperation and integrity.”

(Student 1)

“...Honesty and cooperation is important."

(Student 2)

“...Honesty, discipline, and religious is important for Junior high school students."

(Student 3)

“...Respect, perseverance, and honesty.”

(Student 4)

“...Discipline, honesty, respect and perseverance."

(Student 5)

“...Discipline, honesty, and respect."

(Student 6)

Each student argued that Junior High School students should have characters such as Religious (Spiritual), Honesty, Discipline, Respect, and Cooperation. Those characters were very badly needed in order to live in society. They claimed that character like Religious was the basic item that they should have as a human being, Honesty guided them to tell the truth so people can trust them, Discipline helped them to follow the order, Respect helped them to make peace with everybody, and Cooperation helped them to finish any kind of difficult works together.

\subsection{Understanding values in the textbooks}


Based on the interviews to six students, it can be concluded that all students realized toward character values inside the textbooks that they were using. They claimed that materials inside the textbooks were supported with various character values. Some materials like the words Thanks God and Congratulation were the example of promoting character values. They also claimed that the textbooks they were using also provided character values Related to Self, Others, and Environment. In addition, all students agreed that the presence of character values in the textbooks were presented implicitly in reading text, dialogue and the instruction. The presence of characters in the textbooks was claimed by the students as moderate since they could find it in every chapters.

When the students were asked about the problems in understanding character values in the textbooks, the majority of the students claimed that they did not find any difficulty in learning process. In contrast, one of six students claimed that she found difficulty during learning process. The problem arose since all the characters were implicit. She claimed that it was hard for her to understand what character inside the material and sometimes they unaware of the existence of character values inside the materials. In addition, she said even though the students could find some character values in the textbooks but sometimes they have different interpretation from their friends. Meanwhile, some students suggested that the materials were lots of repetitive materials like in textbook 2 and textbook 3 and need to add more realistic situation as the examples.

\section{DISCUSSION}

\section{Teachers' Perception about Character Values Portrayed in the Textbooks}

Based on the interview, the teachers acknowledged that their current textbooks promoted character education in it. Teachers believed that character education was the key to answer moral degradation that happening in the society and they also claimed that character education was useful to make better young generation in the future. This is in line with the study conducted by Qoyyimah (2015) who revealed that character education can answer social problem. Furthermore, teachers argued that character education should be taught as soon as possible, it is started from family. As Thompson (2002) said that character education is to create people with virtuous values, to apply good behavior, and to practice moral actions. In their opinion, character education could teach students specific character values that were important for them to live in society, especially in school context. They believed that some character values did exist in their in-used three textbooks.

It is a regretful situation when all teachers believed that the textbooks they were using provided character values but they confirmed that they did not know anything about 18 
character values proposed by government. The researcher claimed that this condition happened because it was influenced by some aspects. First, it could be happen because teachers were lack of seeking information by themselves especially about the development and renewal of current curriculum. Second, this condition also reflected that our government through Ministry of Education and Culture were lack of attention in providing seminar or meeting regarding the development and renewal of current curriculum continously to the teachers, especially in regional context. Based on this condition, the researcher assumed that promoting official character values to students in school will be much more difficult since the teachers were inaware about the existence of character values in the textbooks. Moreover, the researcher claimed that the teachers were lack of knowledge and skill about teaching those character values to the students. In accordance, this could hamper students to be good individuals as soon as possible that in line with the goals of curriculum.

In fact, character values in the textbooks were majorly presented implicitly (expressed indirectly) rather than explicitly (plainly and clearly stated). This finding was in line with study conducted by Utami (2015) that found the representation of characters in the textbooks was in form of implicit. Majority of the character values materials were provided implicitly in dialogue. It is also supported by Aslamiyah (2012) in her study who revealed that the integration of character education in the textbooks mainly existed in speaking skill through dialogues. Meanwhile, some animations in the textbooks represented character values explicitly where both teachers and students will understand it from the first sight. Some teachers argued that sometimes they needed to stress character values directly to the students. Since the majority of the character values materials were presented implicitly, teachers needed to pay attention to the existence of character values more careful so it could cover whole provided character values inside the textbooks. even though, from the interviews, all teachers could not recognize eighteen character values that proposed by the government that integrated into the textbooks. Through the awareness toward the existence of character values inside the textbooks, it was expected that it will give big opportunity for teachers in promoting character values and it also gives a chance to students to identify and to absorb various values. On the other hands, teaching character values was not an easy job, so it really depends on teachers' role. Teachers had to become the role model of good individual with noble character in school by giving real action in front of students. In addition, teachers are demanded to have various teaching strategy in delivering character values inside the textbooks to the students.

Since the rule by the government do not allow students to buy textbooks from schools, both students and school experience lack of teaching and learning resources. The schools only used textbooks that allowed by the government as well as students who were Linguists: Journal of Linguistics and Language Teaching Vol. 6, No. 2, December 2020 
only loaned from the school library. Teachers claimed that they sometimes used additional materials in the classroom in order to cover the learning objectives on their syllabus since the textbooks could not make it. But the use of this additional materials just concerning to the fulfillment of language competence rather than character values itself. Moreover, the researcher found that some students did not have the textbooks since the limitation of available textbooks in the library. Looking at this kind of situation, it clearly indicated that the integration of character values in certain subject especially in English subject cannot be optimal in the classroom. In this case, it is really needed the creativity of the teachers in order to provide satisfying materials and promoting character values to students without ignoring the language competence.

\section{Students' Perception about Character Values Portrayed in the Textbooks}

Students claimed that character education is related to an attitude and character education is essential in strengthening their characters. They believe that through character education they will be able to choose what is good and right for themselves. In essence, students could learn character values everywhere, but learning in school will possible since students spent more than half day in school. All students realized toward the existence of character values inside the textbooks that they were using. It can be concluded that students understood and could give example about the character values on it. It can be seen from their opinion which claimed that they could find values Related to Self, Others, and Environment. Even though, it confirmed that students knew about character values in the textbooks but it still needs to guide students to forge characters that they have know become a habit. The main goal of character education is not enough just knowing. As Lickona (2012a) said that character education is about knowing, feeling and acting. Again, in this case it should be underlined that character education really depends on how teachers guide students in attaching character values in teaching and learning process.

Although students said they are aware of the character values contained in the book but it did not mean they have not experienced any problems. First, students argued that it was difficult to learn character values through the textbooks since the character values were presented implicitly. It is hard for students to understand character from the textbooks. Since students were sometimes unaware of the existence of particular values in the textbooks and sometimes they had different interpretation with their friends, it really needs a teacher's guidance. It is also true that sometimes teachers need to stress the values explicitly during learning process. Second, it is better if the materials were designed variously to avoid repetitive materials like in textbook 2 and textbook 3. By presenting repetitive materials, it 
will give the impression that the textbook is boring and it will decrease student motivation in using it.

\section{CONCLUSION}

Teachers' and students' argumentation fully agree that character education is essential in creating good individual with noble characters to tackle moral degradation. Their understanding of character education in the textbooks they were using now were satisfactory. It can be seen through both teachers and students were aware dealing with character values in the textbooks that embedded in the teaching and learning materials which it can be presented both in form of implicit and explicit. Even though the teachers aware of the existence of character values in the textbooks but they did not know about 18 character values proposed by the government yet.

\section{REFERENCES}

Afriani, Z.L. (2019). Character Education in EFL Classroom. Edulingua: Jurnal Linguistiks Terapan dan Pendidikan Bahasa Inggris, 6(2). 69-76.

Afriani, Z.L. (2019). Cultural content analysis of English textbooks used by tenth graders in Bengkulu Utara. LINGUA: JURNAL BAHASA DAN SASTRA, 20(1), 65-76.

Act of Republic Indonesia Number 20, 2003. (2017, February 24). Retrieved from sindikker.dikti.go.id/dok/UU/UU20-2003-Sisdiknas.pdf

Agboola, A., \& Tsai, K. (2012). Bring character education into classroom. European Journal of Educational Research, 1 (2), 163-170.

Aslamiyah, M. (2012). Integration of character education values in English textbooks of Junior High School in Kotabaru Regency South Kalimantan (Unpublished Magister's thesis). Yogyakarta State Univesity, Yogyakarta, Indonesia.

Azimpour, E., \& Khalilzade, A. (2015). Hidden Curriculum. World Essays Journal, 3(1). 18-21.

Battistich, V. (2005). Character education, prevention, and positive youth development. Washington, DC: Charater Education Partnership.

Behera, H. (2016). Educational philosophy of Mahatma Gandhi with special reference to curriculum basic education. International Education \& Research Journal, 2(1), 112-115.

Berkowitz, M., \& Bier, M. (2005). What works in character education: A research-driven guide for educators. Washington, DC: Character Education Partnership.

Creswell, J. (2012). Educational research: Planning, conducting, and evaluating qualitative and quantitative research (4th ed.). Boston, MA: Pearson.

Cubukcu, Z. (2012). The effect of hidden curriculum on character education process of primary school students. Educational Sciences, 12(2). 1526-1534.

Fraenkel, J., Wallen, N., \& Hyun, H. (2012). How to design and evaluate research in education (8th ed.). New York, NY: McGrawHill.

Furkan, N. (2013). Pendidikan karakter melalui budaya sekolah. Yogyakarta: Magnum Publishing.

Inderawati, R. (2013). The Application of literature for all and literature across curriculum concept by responding literary works to the enlightenment of character education in Indonesia context. Journal of Teaching and Education, 2(1). 13-24. 
Lickona, T. (2012a). Mendidik untuk membentuk karakter: Bagaimana sekolah dapat mengajarkan sifat hormat dan bertanggung jawab. Jakarta: Bumi Aksara.

Lickona, T. (2012b). Persoalan karakter: Bagaimana membantu anak mengembangkan penilaian yang baik, integritas, dan kebajikan penting lainnya. Jakarta: Bumi Aksara.

Mei, P. (2015). The hidden curriculum in language classrooms. Sino-US English Teaching, 12(6), 424-429.

Ministry of Education. (2010). Desain induk pendidikan karakter. Jakarta: Ministry of Education.

Mulyasa, H. (2013). Pengembangan dan implementasi kurikulum 2013. Bandung: PT Remaja Rosdakarya..

Otewa, J. (2016). Using hidden curriculum principles in teaching character education in Kenya. Barathon Interdisciplinary Research Journal, 6(Special Issue), 120-126.

Pala, A. (2011). The Need for character education. International Journal of Social Sciences and Humanity Studies, 3(2), 23-32.

Permana, D. R. (2018). Portraying character education in junior high school textbooks of the 2013 curriculum. Journal of English Language Studies, 3(2), 245-258.

Qoyyimah, U. (2015). EFL teachers' professional dilemmas with moral curriculum reform in Indonesia (Unpublished Doctoral's Dissertation). Queensland University of Technology, Queensland, Australia.

Thompson, W. (2002). The effect of character education on students behavior (Unpublished Doctoral's Dissertation). East Tennessee State University, Tennessee, US.

Utami, A. (2015). Analisis pendidikan karakter pada buku siswa Kurikulum 2013 mata pelajaran bahasa Indonesia SMP kelas VII dan X (Unpublished Magister's Thesis). Yogyakarta State University, Yogyakarta, Indonesia.

Yuksel, S. (2005). Kohlberg and hidden curriculum in moral education: An opportunity for students' acquisition of moral values in the new Turkish primary education program. Educational Sciences: Theory and Practice, 5(2), 329-238. 